\title{
Homenagem a Rosa Maria Farah
}

\author{
Leda Maria Perillo Seixas*
}

Sentimos saudade de certos momentos da nossa vida e de certos momentos de pessoas que passaram por ela.

Carlos Drummond de Andrade

Escrever uma homenagem póstuma é sempre uma tarefa difícil: não que faltem atributos à homenageada, mas pela tristeza de não a termos mais entre nós... Todavia, como diz Drummond, saudade também é presença... Sofrer a saudade é trazer para perto alguém que cá não está...

Rosa Farah foi psicoterapeuta e professora do curso de Psicologia da Faculdade de Ciências Humanas e da Saúde da PUC-SP, Universidade onde fez sua formação de graduação e mestrado. Sua dissertação já apontou a nova área de estudos em Psicologia na qual foi pioneira: "Ciberespaço e seus navegantes: novas vias de expressão para antigos conflitos humanos". Criou e coordenou o Núcleo "O Corpo na Psicologia" e o NPPI - "Núcleo de Pesquisas da Psicologia em Informática”, setor responsável pelo Serviço de Informática da Clínica Psicológica Ana Maria Poppovic da PUC-SP; foi também supervisora de estágio de psicólogos do Aprimoramento Clínico-Institucional na mesma Clínica Escola, sendo responsável pela formação de inúmeros psicoterapeutas em São Paulo.

Sua importância no cenário da psicologia do Brasil é bastante signficativa: precursora nas pesquisas de interface psicologia/informática, ministrou diversos cursos e palestras, sendo assessora para o CRP/o6 na

* Professora do Departamento de Métodos e Técnicas da FACHS, curso de Psicologia, coordenadora do Núcleo “O Corpo na Psicologia”. E-mail: lmseixas@pucsp.br 
criação das bases éticas do atendimento via internet. Escreveu dois livros sobre este tema: Psicologia e Informática - O Ser Humano Diante das Novas tecnologias e Relacionamentos na Era Digital, este último em parceria com Ivelise Fortim, além de capítulos publicados em vários livros. Foi coordenadora do Projeto de Orientação Profissional Online, desenvolvido em parceria com a COGEAE.

Foi também graças ao seu esforço que a então Faculdade de Psicologia da PUCSP em 1978 incluiu, e mantém até hoje em seu currículo, a abordagem corporal em psicoterapia. No cenário internacional esta abordagem figura atualmente como importante fonte de pesquisa na recuperação de traumas, distúrbios psicossomáticos e outras alterações psíquicas.

Fez especialização em Cinesiologia no Instituto Sedes Sapientiae e também estudou com Dr. Pethö Sándor, médico húngaro radicado no Brasil, criador das técnicas da Calatonia e Toques Sutis desde 1972 até 1992, ano da morte de Sándor. Escreveu o livro Integração Fisiopsíquica - O Trabalho Corporal e a Psicologia de C. G. Jung, onde expõe o método psicoterápico desenvolvido pelo mestre, publicação importantíssima, uma vez que Sándor deixou poucas coisas escritas.

Foi membro do conselho editorial da Revista Hermes (ISSN 16778979), publicação do Instituto Sedes Sapientiae contribuindo com muitos artigos. Trabalhadora incansável, uma semana antes de seu falecimento em dezembro de 2016 publicou seu último livro, Calatonia, o Toque Sutil na Psicoterapia em duas versões, uma em português e outra em inglês, destinada ao ensino da Calatonia fora do Brasil.

Além de falar sobre sua importância profissional, gostaria agora de dizer algumas palavras sobre a minha amiga Rosa. Nós nos conhecemos há mais de trinta anos nos grupos de estudo com o Prof. Sándor, e desde então nossa amizade só cresceu! Rosa foi parceira em muitos empreendimentos, companheira, boa conselheira, sempre disposta a ajudar no que quer que fosse preciso. Paciente, ouvia a todos, sempre buscando uma posição conciliadora. Era uma pessoa discreta e mesmo assim muito próxima a seus amigos e familiares, carinhosa e atenciosa. Gostava das suas cachorrinhas, 
do papagaio, das suas plantas e mantinha um jardim lindíssimo na sua casa. De tempos em tempos nos brindava com fotos que ela postava das árvores e flores que cultivava.

Rosa soube cultivar bons amigos também, e fico muito feliz de ter sido parte do seu círculo de amizades.

Foi muito difícil começar o ano letivo sem sua presença, mas fica um consolo: Rosa nos deixou de uma forma suave, assim como viveu sua vida: calma, em casa, no aconchego e proximidade de sua família que lhe era muito cara e que era também muito presente em sua vida.

Que sua lembrança permaneça sempre viva em nossos corações! 